\title{
Private Sector Involvement in the Millennium Ecosystem Assessment: Using a UN Platform to Promote Market-Based Instruments for Ecosystem Services $\varnothing$
}

\section{Marie Hrabanski \\ CIRAD Languedoc-Roussillon, Montpellier, France}

\begin{abstract}
The article analyses the implication of private sector representatives in the Millennium Ecosystem Assessment (MEA) (2001-2005). The article shows that, before this international biodiversity assessment, firms were involved in three coalitions: the greenhouse gas pro-trading coalition, the voluntary private standard coalition and the payment for environmental services coalition. These three coalitions all advocated a particular style of regulation that gave overwhelming emphasis to market-based policy instruments. Corporate experts from the three coalitions identified were recruited to participate in the MEA. Thanks to the political visibility given to the ecosystem services concept by the MEA, private industry was able to strengthen and legitimize its actions in favour of market-based environmental governance. At the same time, associating private sector representatives with the MEA process made it easier to disseminate the concept of ecosystem services. Copyright @ 2017 John Wiley \& Sons, Ltd and ERP Environment
\end{abstract}

Received 28 March 2017; revised 19 June 2017; accepted 4 July 2017

Keywords: biodiversity; ecosystem services; global governance; market-based instruments; millennium ecosystem assessment (MEA); private sector

\section{Introduction}

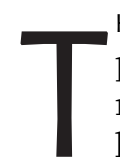

HE BUSINESS SECTOR HAS LONG HAD A HAND IN FORMULATING INTERNATIONAL STANDARDS AND POLICIES. THIS WAS ACHIEVED IN part through its lobbying of national governments and in part through the participation of business representatives in commissions of international organizations. Industry has often been represented by groups largely opposed to stronger international environmental protection policies. However, in the ig9os the nature of the commitment of multinationals changed (Le Prestre, 2005). The participation of private companies in the 1992 United Nations Conference on Environment and Development, also known as the Rio Earth Summit, marked the official arrival of business in international environmental politics. 
Among its various outputs, ${ }^{\mathrm{I}}$ the conference helped to firmly anchor climate and biodiversity issues on the international political agenda, by adopting the United Nations Framework Convention on Climate Change (UNFCCC) and the Convention on Biological Diversity (CBD). While business quickly showed an interest in climate change matters, it was much slower to embrace biodiversity questions as a global issue. Nevertheless, a movement began to emerge in the early I990s, notably around certain market instruments for biodiversity conservation such as voluntary standards and compensation mechanisms. This movement continued and, by the end of the I990s, the literature and initiatives proclaiming market-based instruments (MBIs) were thriving, despite some confusion surrounding the concept of $\mathrm{MBIs}^{2}$ (Broughton and Pirard, 20II). A few multinationals became interested in the political and financial opportunities positive incentive measures seemed to offer (and not negative price signals such as taxes), but such approaches remained sectoral and not widespread.

It was in this context that private companies became associated with the United Nations Millennium Ecosystem Assessment (MEA) at the end of the I990s (Pesche et al., 2013). Beyond delivering a shattering analysis of the degradation of ecosystems worldwide, the MEA brought into politics a reference that has become unavoidable in public environmental and agricultural policies internationally: the ecosystem service (ES) concept (Méral, 20I2).

The private sector was involved in the MEA through the intermediary of the WBCSD (World Business Council on Sustainable Development), a transnational group of companies working for sustainable development. One of the main problems was to develop the credibility of the process by basing it on scientific expertise and at the same time to involve stakeholders to legitimate and disseminate knowledge and norms produced by this assessment. Thus, the MEA can be regarded as a formal effort to assemble selected knowledge to make it publicly available in a form useful for decision-making (Mitchell et al., 2006). In this way, Mitchell et al. think that global environmental assessments should be seen as social processes rather than simply in terms of the documents they produce. It is therefore a matter of precisely analysing the implications of private sector representatives in this international biodiversity assessment. Thus, there are two research questions explored in this paper: How were private sector representatives involved in the MEA? And what business interests were served by their involvement in the MEA? With the answers to these questions, this article complements the existing explanations of the building of environmental global governance by focusing on the key role played by business in promoting MBIs for biodiversity and ES.

In the following, the argument regarding the role of business representatives in the diffusion of MBIs in biodiversity unfolds in four steps. First, there is an analysis of the links between the concepts of ES, payments for environmental services (PES) and MBIs during the MEA. In the next part, the idea of an 'advocacy coalition framework' (ACF; Sabatier and Jenkins-Smith, I993) is introduced as a conceptual lens for studying business involvement in the MEA, and the methodology is presented. Thereafter, the findings regarding the above research questions about the involvement of business representatives in the MEA and the underlying business interests are developed.

\section{The Millennium Ecosystem Assessment}

Since the 1992 Rio summit, global environmental changes have become a growing preoccupation and global scientific assessments have become more and more frequent. These assessments, like the MEA, can be regarded as a formal effort to assemble selected knowledge to make it publicly available in a form useful for decision-making (Mitchell et al., 2006).

While the MEA formally took place from 200I to 2005, preparations were already under way in late I998. A preliminary exploratory committee, set up on the initiative of the United States-based World Resources Institute (WRI), the World Bank and the United Nations Development Programme (UNDP), operated from I998 to I999. Its composition was a good reflection of the nature of the process, with fairly balanced representation between noted scientists (some with political or institutional responsibilities), representatives of international organizations - the

\footnotetext{
IGovernments adopted three main documents, the 'Rio Declaration', a detailed action plan called 'Agenda 2I' and a 'Declaration of Principles, not legally binding but conferring authority for world-wide consensus on the management, conservation and ecologically viable exploitation of all types of forests' (Forest Principles). The Rio summit was also the occasion for the signing of the CBD and the UNFCCC.

${ }^{2}$ Broughton and Pirard (20II) highlight the confusions surrounding the concept of MBIs and show that there is no archetypal market instrument, but rather possible derivatives of it, with highly variable characteristics.
} 
World Bank, UNDP, the United Nations Environment Programme (UNEP), and the Food and Agriculture Organization (FAO), and more specifically members of the secretariats of relevant multilateral environmental agreements - the CBD, the UN Convention to Combat Desertification (UNCCD) and the UNFCCC.

From 2000 on, the MEA process was managed by a Board that reflected the concern to mobilize different stakeholder categories around the issue of assessing ecosystem degradation: it had the same participant profiles as the exploratory committee, with the addition of representatives of governments, non-governmental organizations (NGOs) and the private sector. This multistakeholder aspect of the MEA process gave it legitimacy and was undeniably a factor in disseminating the knowledge produced, via the various networks involved (Pesche et al., 2013). The process has mobilized nearly 1360 experts from science, governments, international organizations, NGOs and companies for more than 4 years, both to contribute to drafting the assessment documents and to their proofreading.

Ultimately, there were relatively few private sector representatives among the experts involved in the MEA. However, they were present in all the most influential bodies of the process. These include the Board: three representatives out of 49 members come from private sector; and the MEA scientific networks, notably the team that drafted one of the synthesis reports of the MEA, because eight authors out of 16 come from the private sector.

Altogether, the outputs of the MEA included a general overview and five synthesis reports, each targeting a specific audience: biodiversity, desertification, wetlands, the private sector and the health sector. The work of the ES promoters did not end with the publication of the MEA reports in 2005 (Pesche et al., 2013): the 'MEA coalition' Q4

in favour of the ES approach remained active and gradually changed to address the dissemination of the ideas developed during the MEA. The ES concept was progressively incorporated in international and national arenas (Hrabanski et al., 20I3). Among the MEA's most significant contributions was the proposal of an analytical framework incorporating ES, now embedded in the scientific literature ${ }^{3}$ (Jeanneaux and Aznar, 20Io) and in public policy, and to draw the international community's attention to the monetary value of ecosystems and the economic costs of inactivity. The main event illustrating this trend is the emergence of The Economics of Ecosystems and Biodiversity (TEEB) initiative.

\section{Connections and Controversies between the Concepts: 'ES', 'PES' and 'MBIs'}

The MEA promoted the concept of ES into the national and global realm of environmental governance. However, during the MEA, the private sector did not attempt to spell out all conceptual dimensions of ES, but focused mainly on the economic opportunities offered by a payment for an environmental services approach and MBIs more generally. The links between these different concepts need to be clarified.

At the end of the I990s, the MEA sponsors shared the conviction that highlighting the idea that ecosystems produce services was a strong argument for changing decision-makers' thinking with regard to the growing environmental degradation which by then was receiving increasing attention from the media. They argued that to improve human wellbeing, the supporting services (e.g. nutrient cycling, soil formation), provisioning services (e.g. food, timber, fuel), regulating services (e.g. climate, flood regulation) and cultural services (e.g. recreation) provided by ecosystems must be taken into account.

Recent studies on the history of ES and PES conceptualize payments for environmental services as policy implementation of the ES concept in a global process of commodification (Gómez-Baggethun et al., 20IO). According to the canonical definition by Wunder (2005: 3), a PES is 'a voluntary transaction where a well-defined ecosystem service (or a land-use likely to secure that service), ( ...) is being "bought" by a (minimum one) ES buyer, from a (minimum one) ES provider, if and only if the ES provider secures ES provision (conditionality)'. This definition was taken up and commented on in numerous subsequent publications (Engel et al., 2008; Farley and Costanza, 20I0; Muradian et al., 20IOa, b). In this way, PES are now understood because of the MEA process in mainstreaming ES into conservation and environmental policy (Redford and Adams, 2009). However, Pesche et al. (2013) explored the relationship between ES and PES more precisely and showed that two relatively independent and contemporary processes, at least during the I990s, led to the emergence of the ES concept on the one hand and the PES concept on

${ }^{3}$ A bibliometric analysis from Jeanneaux and Aznar (2010) shows a continuous increase of scientific publications on the topic of ecosystem services/environmental services between I999 and 2009. 
the other (Pesche et al., 2013): whereas the concept of ES is closely linked to a desire of ecologists (e.g. Ehr 2 and Ehrlich, I98I) to attract official attention to the threats to ecosystems posed by human pressures, the concept of PES seems to have stemmed from a concern to ensure funding for conservation in tropical countries over the long term (Landell-Mills and Porras, 2002; Wunder, 2005). During the MEA, the ES and PES epistemic configurations drew closer. The private sector and NGOs were more sensitive to the operational side of PES. One of the ideas developed in the MEA was to counter ecosystem degradation through 'greater use of economic instruments and marketbased approaches' including taxes and user fees, creation of markets, payments for ES and certification (M, 0 k005: 2I-22). At first largely independent of practical experiments with PES or PES-like instruments, the concept of ES is Q6 now closely involved in decision-makers' growing interest in the idea of MBIs for ES. Thus, MBIs for ES comprise a large array of policy instruments designed to modify the behaviour of land users or natural resource managers in ways that maintain or promote ES.

There are many controversies around these three notions (Barnaud and Antona, 2014). Indeed, several papers in the recent critical geography literature have analysed various PES programmes and pointed out that, although PES are commonly considered a paradigmatically neoliberal market-based conservation mechanism, most of these programmes actually do not strictly follow the pure neoliberal vision (Dempsey and Robertson, 20I2; Fletcher and Breitling, 20I2; Shapiro-Garza, 2013). Beyond that, there are controversies around the very use of monetized and market-based mechanisms to deal with conservation matters (Maris, 20I4).

One can argue that this is not specific to ES - some environmental market-based mechanisms existed before the launch of the concept of ES into policies. However, ES are nowadays commonly associated with the idea of PES, and more generally with a neoliberal vision of conservation. Matulis also claims that 'The proliferation of market-based approaches to conservation is, in many ways, antithetical to ensuring social and ecological well-being' (Matulis, 20I4: I56). However, first, Corbera (2015) explains that PES are very rarely implemented to result in markets (Schomers and Matzdorf, 2013) and, even when they involve private and other non-state parties, they should probably be regarded as 'contractual' transactions at best (Wunder, 2005). If PES rely on state budgets and operate as subsidies, we are dealing with a public policy aimed at changing the relative costs and benefits of land-use options, rather than with a new market. Furthermore, MBIs constitute an extremely heterogeneous group that makes little sense from an economic theory perspective. MBIs as a category look more like an asylum country for all tools with a price component (Pirard, 20I2; Boisvert et al., 20I3). Second, Sikor, who seeks to reconcile positions of critics and proponents of ES, suggests that we should think of environmental management as creating both justices and injustices simultaneously (Sikor, 2013).

\section{Analytical Perspectives: The ACF in Clobal Environmental Politics}

How can we make sense of the role played by business in producing international policies? In political sciences, the ACF develops a micro-level view on the role of stakeholders (including business) in international politics, to avoid decontextualizing the research on international environmental regimes. Peter Haas's study on epistemic communities ${ }^{4}$ (Haas, I992), inspired by regime theory (Krasner, I983), allows the consideration of the role of businesses as knowledge-brokers, co-constructing what is and what is not policy-relevant knowledge. But much of the epistemic community research focuses on scientific expertise as an objective form of knowledge capable of reducing the uncertainty that characterizes environmental problems, and building consensus in favour of international cooperation (Levy and Newell, 2005). Haas neglects to analyse the contested nature of knowledge, where private companies and NGOs are actively engaged in supporting particular interpretations of scientific evidence (Orsini, 20IO). In this paper, it is assumed that corporate expertise is an important currency for gaining political access, and that corporate expertise can be a way to represent interests (Coen, 2005; Grossman and Saurugger, 2006; Hrabanski, 2010).

Regime theory remains macro-level views, and it is important to complement it from a micro-level perspective to better understand the concrete mechanisms at work when companies engage in international politics. The ACF proposed by Sabatier and Jenkins-Smith (I993) allows reconciling macro- and micro-level views. The approach is

\footnotetext{
${ }^{4}$ Haas (I992) uses the epistemic community concept to highlight the sharing of beliefs of a scientific type over principles and causalities, but also a convergence of interests within a group of heterogeneous stakeholders mobilized with a view to influencing political processes.
} 
defined as including 'people from various governmental and private organizations who both share a set of normative and causal beliefs and engage in a non-trivial degree of coordinated activity over time' (Sabatier and Jenkins-Smith, I993). In this way, the coalition is a group of actors who are bound by a similar belief system and promote the same policy option. The policy changes are then the results of the balance of power between different coalitions of actors within a policy system, and/or the learning process inside dominant coalition. In addition, unlike the 'epistemic community' concept of Haas (I992), Sabatier and Jenkins-Smith (I993) favoured the coalition notion over the term 'epistemic community': while the latter suggests the idea of a closed shop, the former places more emphasis on the open and moving dimensions of the configuration. In other words, from this perspective, business participation in the MEA was a way for the private sector to be in the science policy arena and to pool frames of reference with decision-makers, scientific experts, NGOs, etc. The ACF highlights the role of people in these dynamics. In the MEA configuration, private sector representatives presented not their companies but themselves and were presented by others as 'experts', just like all other MEA experts. Some of the private sector experts involved later even moved on to a position in a major NGO, or within an administration. Finally, the ACF enables us to consider the representation of interests as a long-term process which consists of constructing and sharing common references with multiple stakeholders. Where applicable, this kind of advocacy coalition is a way for business to be involved in biodiversity policies. This literature highlights the importance of the cognitive dimensions of stakeholders and also of looking at the earlier processes through which the stakeholders within the advocacy coalition were selected or excluded.

\section{Methods}

This article is based on a broad methodological framework from two scientific projects (the SERENA and INVALUABLE projects), ${ }^{5}$ which deal with the genesis and the implementation of ES approaches and MBIs for biodiversity. More than 70 experts (international organizations, NGOs, think tanks, governments, etc.) were interviewed. A part of the study was about the role of the private sector in these dynamics and, more precisely, we use several methods to analyse the participation of private sector representatives in the MEA. Initially, we interviewed I8 key stakeholders of the Millennium process from January 20I0 to January 20I2. During its tenure, the MEA mobilized more than I360 'experts' around the world, but an analysis of the overlapping responsibilities and varied degrees of involvement points to the core author team of the synthesis report on 'Opportunities and Challenges of Business and Industry'. Among these I 6 authors, eight come from the private sector, six of whom we interviewed. We also interviewed three representatives of international organizations and nine of scientific communities, who were on the MEA's Board or in one of the scientific bodies (assessment panel and editorial team). These I8 semistructured expert interviews allowed us to analyse the trajectories of the MEA process, the motivations of the people involved as well as technical issues such as the methods of recruitment to the MEA.

Thanks to access provided by members of the MEA Board, we also analysed the archives of the MEA and many documents produced by the MEA to analyse the different positions around MBIs for ES. Finally, an analysis of grey literature from the WBCSD, and notably of the WBCSD's I5 publications produced on biodiversity between June I997 and October 20I0, was the basis for analysing how the WBCSD as an important business organization involved in the MEA process appropriated the ES concept in a selective way.

\section{Results}

Based on empirical research, this paper shows that at the time of the MEA, an advocacy coalition emerged in favour of MBIs for ES and biodiversity. This coalition was composed of stakeholders from multiple social worlds (NGOs, national administrations, the private sector and international organizations) who were attempting to develop market-based regulation mechanisms in the biodiversity sector. The empirical framework also highlights that before

5http://www.serena-anr.org/ and http://invaluable.fr/ 
the MEA, the private sector representatives belonged to three pre-existing coalitions already interested in incentive mechanisms for environmental policy. We show that with the advent of the MEA, the pre-existing coalitions persisted but a new coalition of heterogeneous stakeholders, based on the three pre-existing coalitions, participated in spreading the concept of ES and MBIs to promote the introduction of ES markets.

\section{Some Mentors of Business Involvement in the MEA: Advocacy Coalitions Promoting MBIs in the 1990s}

Already after Rio in 1999 quite a number of companies became involved in environmental issues. The companies involved were based on business models that depended heavily on natural resources, and they gradually started to take part in the international biodiversity assessment in promoting some kinds of MBIs.

From the Greenhouse Gas 'pro-Trading Coalition' to the International Biodiversity Assessment of the MEA Of the eight business members of the team who drafted the MEA's 'Opportunities and Challenges of Business and Industry' synthesis report, two came from the greenhouse gas (GHG) pro-trading coalition, notably the former CEO of BP Americas. During the international climate change negotiations of the I990s, a business-NGO coalition emerged that promoted emissions trading - an emblematic market-based mechanism (OECD, I997, 2003, 2007; Pirard, 20I2). Meckling (20II) used the advocacy coalition approach to describe business involvement in climate issues in the I990s. The author shows how, before I990, the dividing line between the coalitions had been between 'anti-regulation coalitions' and 'coalitions in favour of command and control type measures' (Meckling, 20II.: 43). Meckling shows how a third coalition appeared at the beginning of the I990s, the 'pro-trading coalition' in favour of carbon trading. This last coalition encompassed NGOs and business, and was a more powerful lobby group in the Kyoto climate negotiations than in the European Union (EU). The members of the coalition gradually relied on scientific experts and on allies from national administrations (United States) and supranational administrations (EU) to develop a market-based regulation of GHG mitigation. This coalition was based on a shared preference for a type of market-based GHG governance as the lesser evil compared to a regulatory approach, and on a will to develop carbon market instruments, such as GHG emission quotas, by influencing decision-makers. The leaders of this coalition included BP and Dupont. In our interview with the former CEO of BP Americas in April 2OII, he stated: 'When I was with BP we were, you may recall, or maybe you don't recall, we were very active on the issue of climate change. And we were instrumental at developing internal trading regimes to help us reduce our own emissions. I got involved with MBI approaches to solving environmental problems back in the gos with BP.'

Another expert (anonymous) from the private sector was also involved in the Kyoto climate negotiations and he also stated, 'market-based instruments are more efficient and more flexible, that is why it's better for us because we are in favour of sustainable development'.

The ACF puts forward the notion of 'coalition' as a group of actors who are bound by a similar belief system and promote the same policy options. Through these two interviews, we can observe that both representatives of the private sector share the belief that 'the private sector is a part of the solution for climate change, and my firm must be involved in the climate negotiations', as well as the same policy option, which is the use of tradable permits for GHGs. They share the same values and the same belief in the efficiency of tradable permits and more generally of MBIs. In other words, in being involved in the MEA, the GHG pro-trading coalition introduced a learning process inside the coalition in favour of the ES approach, which consisted in promoting environmental market-based approaches. Furthermore, Meckling shows that, although business could not prevent the control of emissions, it could influence the type of regulation in favour of market-based regulation. Business therefore had a considerable influence over the style of political regulation, and recruitment of the members of this coalition to the MEA was bound to facilitate the transfer of public policy solutions from the climate regime (Paterson, I993; Dahan Damedico and Guillemot, 2006; Stephens et al., 20II) to the biodiversity regime (Ezzine-de-Blas et al., 20I6).

From the Transnational Coalition of Voluntary Private Standards to ES

The second coalition from which private sector representatives were recruited to the MEA was the transnational coalition of voluntary private standards. Voluntary private standards belong among 'voluntary price signals', which according to Pirard are a category of MBIs that 'consists in schemes whereby producers send a signal to consumers that environmental impacts are positive (in relative terms) and consequently gain a premium on the market price' 
(Pirard, 2012: 65). Fouilleux showed that since the end of the I990s, a coalition on voluntary private standards comprised 'collective and individual stakeholders, mobilized by a certain number of common beliefs and values, who interacted around the promotion and gradual adjustment of voluntary certification mechanisms as efficient regulation instruments to oversee globalization' (Fouilleux, 20I0: Q 2 ). Four representatives from pioneering Q7 companies in certification matters were included into drafting the Synthesis MEA on business: for instance, among the MEA experts, the chairman of Unilever, at the end of the I990s, had been personally involved in founding the Marine Stewardship Council (MSC), based on the model of the Forest Stewardship Council (FSC). ${ }^{6}$ Being head of the Unilever 'ice cream and frozen foods' division and notably in charge of the 'fish' operations during the I990s, the FSC inspired him. It was a means to counter the erosion of fish stocks worldwide which threatened to put Unilever's fish line out of business (Wolff and Schmitt, 2009). So Unilever created, in partnership with World Wild Fund for Nature (WWF), the MSC which as of 1999 internationally certified seafood products from comparatively healthy fisheries. Another MEA expert was a representative from mining multinational Rio Tinto, one of the largest mining companies in the world. He had been particularly interested in initiatives to preserve biodiversity, notably through compensation and certification. Rio Tinto led international certification initiatives in the metals and mining equipment sector within the International Council on Mining and Metals (ICMM), launched in 2006 jointly with the International Union for Conservation of Nature (IUCN). The Rio Tinto representative stated: 'To make sustainable development attractive to corporate mindset, we proposed some kind of trade-off between economic, social and environmental dimensions of sustainable development, and these kinds of trade-offs, such as ICMM could become a model for environmental governance.' The ICMM is also based on the FSC model. Representation of the Syngenta Foundation fits in with the same approach, with the foundation taking an active part in international forest certification. Lastly, while the Swedish multinational construction and development company Skanska does not depend directly on natural resources, it introduced certified environmental management systems as early as I998 and their vice-chairman and head of the company's environmental affairs launched some quite similar initiatives. At the time of the MEA, Skanska was the largest company in Sweden to have its own certified environmental management system. These four experts have similar beliefs: 'private sector is a part of the solution, and my firm must be involved in the environmental negotiation' and the same policy option, which is the use of certified environmental management, a kind of MBI. These experts in favour of voluntary private standards are involved in a learning process inside the coalition in favour of ES approaches, which consists of promoting environmental market-based approaches.

To sum up: all corporate experts involved in the author team of the 'Opportunities and Challenges of Business and Industry' synthesis report had histories in creating voluntary private standards, a kind of MBI.

From the Coalition of PES to the MEA

Lastly, the third coalition from which private sector representatives were recruited into the MEA process operated in favour of PES. Before the MEA, most PES promoters belonged to quite restricted circles of people from the private sector and public sector working in intertropical forest zones on forest conservation and exploitation matters (Pesche et al., 2013). Of the eight private sector representatives co-authoring the Millennium Assessment synthesis report on 'Business and Biodiversity', two had their origins in the PES coalition. The first comes from Rio Tinto and was involved with the Katoomba group, an organization founded in 2000 to produce scientific data on PES, and now mandated more broadly to promote environmental MBIs. At the same time, this individual was also involved in the voluntary private standards coalition. The second company representative was directly involved in the forestry sector to implement payment for environmental services for a timber industry. Both were members of the WBCSD. One of the contributors to the 'Opportunities and Challenges of Business and Industry' synthesis report was Stefano Pagiola, a member of the World Bank's environment department and leading promoter of PES. His presence on the editorial board for the 'ES and industry' report was a factor in aligning ES and PES instruments more closely in the MEA. At the interface between the science world and the international arena, Stefano Pagiola has acted as a broker for the idea of PES.7 In the late I990s he was working with Michael Jenkins, then senior forestry adviser to the World Bank. In I998, he founded the NGO Forest Trends, which was to give rise to a number of 'incubator' organizations

\footnotetext{
${ }^{6}$ The FSC is a certification mechanism created in I993 following the Rio Summit, governed by civil society groups, ecologists and private firms with a view to ensuring that the production of wood-based products respects procedures designed to guarantee sustainable forest management. ${ }^{7}$ Pagiola also participated upstream in designing the MA's analytical framework.
} 
that favoured MBIs, such as the Katoomba group (2000), BBOP (2005), Ecomarketplace, SpeciesBanking.com, ForestcCarbonPortal.com and the Chesapeake Fund. Some of these incubators work to produce scientific data on PES (Katoomba). Pagiola and Wunder are involved. The findings are fed to the satellite organizations working to set up MBIs that particularly interest some companies and public authorities. As with the two previous coalitions, the coalitions in favour of PES share some beliefs: the 'market is more efficient to solve environmental problems' and the same policy options, namely PES and more generally MBIs.

The careers of some of the MEA report's authors reflect not just the connections between the conservation economics world, the international political arena and the private sector (WBCSD, Rio Tinto, Unilever, etc.), so facilitating the circulation ideas on voluntary private standards, PES instruments and tradable permits in different circles. They also reflect growing interactions between the ES and the three coalitions within the MEA process. These connections intensified during the MEA because voluntary private standards, PES and more generally MBIs could achieve more media coverage and reach other stakeholders who might be interested in the approach.

\section{Corporate Involvement in the MEA}

The Catalytic Role of the WBCSD in International Environmental Governance

From the beginning of the MEA preparatory committees, two foundations financially backed the initiative on a large scale, notably the Packard Foundation (\$0.35 million) and the Avina Foundation (\$o.6 million between I998 and I999) (GEF, 200I). The first followed a tradition of research patronage in the United States. The second, Avina, is a philanthropic foundation created in 1994 by Stephan Schmidheiny, who several months after founding Avina established the WBCSD. Other foundations contributed to the Millennium process in a less sustained manner.

To understand the outstanding role of the WBCSD in these dynamics, we need to return to its creation. In I992, Maurice Strong, who was Secretary General of the United Nations Conference on Environment and Development (Earth Summit, Rio de Janeiro) and a former director of petroleum and hydraulic corporations, teamed up with Stephan Schmidheiny, a wealthy Swiss businessman, to develop links between the international environment community and the private sector. Strong awarded him the post of Principal Advisor to the Secretariat for Business and Industry at the Earth Summit. In I990, during preparations for the Summit, Schmidheiny founded the 'Business Council for Sustainable Development' (BCSD), a precursor to the WBCSD, to promote sustainable development in the business world. He published, in I992, the 'Changing Course' report signed by the BCSD and the World Industry Council for the Environment (WICE) [which at the time represented the International Chamber of Commerce (ICC)]. The report enshrined the role of business in environmental governance, but especially pleaded in favour of self-regulation by business. According to Maurice Strong, the Secretary General of the Earth Summit, the report was one of the most influential documents at the Summit, and more generally the idea was very warmly welcomed by decision-makers (Le Prestre, 2005). The report highlighted various advantages that could arise from environmental initiatives, since whatever the examples or approaches taken by the study, and those that it inspired, environmental challenges seemed most of the time to be a way of improving company productivity and competitiveness (Boiral, 2005). In addition, 'Changing Course' highlighted the capacities of companies to self-regulate, which was in line with the suppression a few months before Rio of a binding international code of conduct for businesses, the UN Centre on Transnational Corporations (UNCTC) code. The idea of such a code had initially been launched at the end of the I970s but was abandoned under pressure from the ICC and the United States. In its place, the BCSD approached the ICC, and they both proposed a voluntary code of conduct for companies based on the reconciliation of economic interests and environmental interests, as promoted by the sustainable development concept (Clapp, 2005). Beyond the charters that preceded the Earth Summit, the challenge for the BCSD and the ICC was to develop regulatory methods that would take into account environmental challenges while being primarily orientated towards the market and based on self-regulation (Clapp, 2005; Clapp and Dauvergne, 2005). Following a merger between the WICE and the BCSD in I995, the WBCSD was founded and promoted the internationalization of business alliance dynamics in favour of sustainable development. Links were woven at the time between the carbon pro-trading coalition and the WBCSD. In line with this constellation, the first Executive Secretary of the WBCSD was Rodney F. Chase, Deputy Group Chief Executive of BP. Vormedal (2008) argues that one of the objectives of the WBCSD is to establish flexible regulation by the market, and in this respect, the WBCSD proves to be particularly averse to 
the quantification of environmental objectives and to restrictive regulation like the pro-trading coalition founded by BP (Meckling, 20II). In other words, the dynamics of self-regulation studied here were the fruit of coalitions and of specific strategies implemented by business in favour of flexible types of regulation.

Recruitment of Corporative Representatives to the MEA

According to the interviews conducted, it was the WRI that was in charge of recruiting private sector representatives. ${ }^{8}$ Jonathan Lash, who was the chairman of the WRI during the MEA process, also presided over the US President's Council for Sustainable Development (PCSD). This task force launched by Bill Clinton had met regularly between I993 and I999, produced many publications and became strongly involved in the MEA. Meckling shows how, by publicizing ambitious environmental objectives, the Clinton administration became a natural ally for partisans of the companies in favour of market-based regulation assembled within the International Climate Change Partnership (ICCP), which was the first business organization to advocate market mechanisms as part of a climate treaty (Meckling, 20II). The ICCP's role was closely linked to the emergence of BP as an outspoken advocate for market mechanisms (Meckling, 20II). Our empirical researches have shown that the business representatives involved in the PCSD were those who were also called upon in the MEA. For instance, the ex-CEO of BP Americas, who co-chaired the PSCD task force on climate change and who was the leader of ICCP, was approached by Jonathan Lash and John Ehrman (Meridian) to become vice-chairman of the MEA 'Opportunities and Challenges of Business and Industry' synthesis reporting group.

Two essential ideas arise. The first is that the recruitment process shows the importance of national dynamics, especially within the United States, in the international assessment process. The second aspect is that the presence of the selected business representatives in the MEA arose from a targeted selection processes: only individuals from companies promoting a certain framing of environmental issues, notably in favour of market instruments, were included. As Meckling shows, the other companies which were in favour of command and control type measures, or against all forms of regulation, or were not affected by environment issues, were excluded. Business involvement in the MEA was by invitation, based on the companies' support for market environmentalism.

The MEA Process: A Consensus on Market Mechanisms between Corporate Experts

The private sector showed interest in all those economic instruments providing positive incentives, and was more sensitive to the operational dimension than the conceptual dimension of ES. In the early 2000 , major multinationals expressed increased interest in MBIs for protecting biodiversity, and even during the MEA process some were active in setting up PES mechanisms and MBIs. The companies Lafarge and Rio Tinto, for example, were leaders in ecological compensation mechanisms. From the outset, the private sector actively supported the initiative via the Avina Foundation, which became one of the MEA's first financial partners.

Although the number of individuals from the business sector was not large in the MEA (to recap: three in the board, eight in the synthesis 'Ecosystem and Human well-being: Opportunities and Challenges of Business and Industry'), the depth of their involvement demonstrates the relative importance given to the MEA by leading proponents of market mechanisms. The two co-chairs of the MEA synthesis reports, 'Ecosystem and Human well-being: Opportunities and Challenges of Business and Industry', were the ex-CEO of BP Americas and Jane Lubchenko. The latter was on the WRI Board and was well-known for her publications on climate change and appearances in the United States Congress. She is known to promote the links between science and business to develop a green economy.

According to the interviews, the different members of this author team had very few interactions, and the report was mainly written by the two co-chairs. One private sector representative related, 'one of the co-chairs required some sections about the corporate image, the reputation and the brand risk, so I sent several elements ... In the same way, I told them that it was important to be concrete, because the report should be useful for firms, and all authors' team agreed ... You have surely seen that in the report there are lots of maps and figures and some others graphical things ... And all these elements were proposed by the chairs, so for us it was very easy, they were very proactive, for us, it was just to confirm and to be precise about some details...'. According to the ex-CEO of BP Americas, 'there was quite a bit of consensus on the substance. So there wasn't a lot of tension during the drafting

${ }^{8}$ Jointly with the Meridian Institute. 
of the synthesis, between the authors' team and between the reviewers, it was very easy, the tension came earlier in the MEA'. The impact of the coalitions in favour of MBIs and the representatives they sent to the board had an indirect impact on the framing and the scientific discussions within the MEA. These people were not involved in the scientific discussions but in the synthesis which deals with the business opportunities. In being involved in producing a synthesis, they indirectly influenced the framing of the scientific discussions. They used the concept of ES immediately as a way to develop MBIs and in this way they influenced the scientific debates. Indeed, the synthesis came after the decision to concentrate on ideas that could be useful to business. The two main topics marked with tension had emerged earlier in the process.

The first of these topics, which created tensions between members of the environmental community and economists, was about the wisdom of the ES concept. 9 The second was the basic question 'of whether or not you best solve problems though strict regulation or (... ) by using market mechanisms' (interview with ex-CEO of BP Americas). This question was not debated among business representatives involved in the synthesis, but before, among the MEA's board and scientific panels. In these discussions the idea prevailed that the MBI model could be more effective, and this result was reflected in the synthesis report. The concept of MBIs implicitly acknowledges companies as legitimate stakeholders, as illustrated by the statement of a BCSD representative and MEA Board member: 'For us it was to show, ... it was important to show that people could trust us, we had understood that we were concerned and we have to be responsible. ${ }^{\text {IO }}$ At the same time, for the promoters of the MEA it was necessary to include private sector participation to emphasize the multi-actor aspect of the MEA and enhance legitimacy, which became an undeniable factor in disseminating the knowledge produced, via the private sector networks involved.

\section{Selective Appropriation of the ES Concept by WBCSD Businesses: Production and Transformation of an ES Stance}

In the following we show how over time the WBCSD, as a particularly relevant business organization in the sustainability context, appropriated the ES concept and how it took part in promoting the concept, or more precisel, certain dimensions of the concept in the aftermath of the MEA.

The analysis of the above WBCSD publications reveals a rise in the influence of the ES concept beginning in 2006. In the I997 document, no mention is yet made of the ES concept; the text is more targeted towards inviting companies to play a greater role in international environmental governance. In November 2006, the WBCSD published a fourth report that marked the take-off of the ES concept - it is in the report title, and occurs approximately 30 times in the text. The document, which was jointly drafted with the WRI, the Earthwatch Institute, the IUCN and the WBCSD, took up some of the results of the MEA, notably the four types of ES and the 24 sub-services. However, the ES concept, such as it is presented in WBCSD publications after 2006, has evolved when compared to the definition proposed in the MEA report.

Three major cases of creep are identified. The first concerns the systematic association of the ES concept with monetary valuation, an idea that according to our interviews was controversial within the MEA. But the WBCSD was concerned with giving real substance to the ES concept, and monetization enabled such concretization. It assembled a set of actions under the ecosystem umbrella, some of which had not previously been associated with any ecosystem approach. Under this umbrella certain companies saw their initiatives, such as certification and compensation systems, and measures in favour of ecotourism and reforestation, re-qualified as measures promoting ES. Even cultural services, the fourth type, which tended to be overlooked in the early WBCSD publications on ES (focused on regulation and supply services), eventually come to the fore when the economic opportunities offered by ecotourism are highlighted.

The second example of creep arises from the first, in so far as the emphasis on ES monetization gradually and 'naturally' opened up the way for genuine ES markets. In the 2007 report, entitled 'Market for ES: New challenges and opportunities for business and the environment', the WBCSD clearly emphasizes the association between ecosystems and their monetization, and supports the emergence of some ES markets, to complement the existing

\footnotetext{
${ }^{9}$ According to some ecologists, the ecosystem services concept was not really relevant in scientific terms. It was more a strategic concept to alert politics rather than a scientific concept. Some scientists were also worried about the commodification of the nature which is implied in the concept.

${ }^{10}$ Interview of the BCSD's representative in Brazil, a member of the author team, in April 20II.
} 


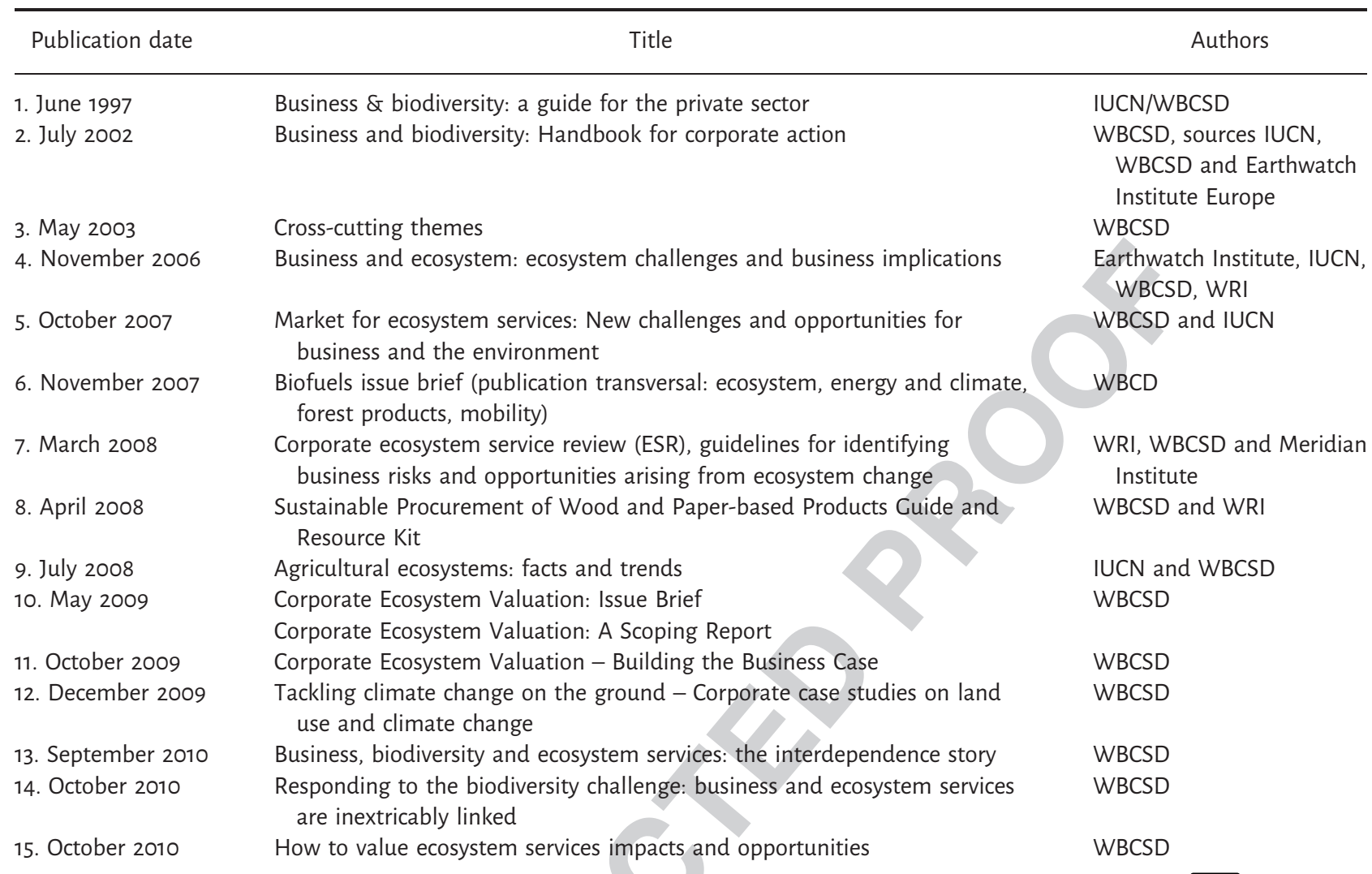

Table 1. The world business council on sustainable Development's publications on biodiversity between 1997 and $201 \Omega$ Source: own compilation.

carbon market. The authors use the term 'ecosytems services' almost 60 times and propose three ways of helping to develop an ES market. The first is to draw up incentives for managers to provide more ES, thereby becoming aware of producing them. The second is to establish tradable permits, and the third avenue to be explored is certification. In the report, the authors even go as far as to identify the five stages that enable one to become 'a good trader of ecosystem services'.

We find a third case of creep in the framing of biodiversity challenges and ES. While the 2003 report emphasizes the role of nature as a free provider of ES, in the 2007 report it is no longer nature that provides ES. Instead, the report places the emphasis on economic operators or those able to provide such services. They thus must be remunerated, thereby opening the way for a biodiversity market. In this perspective, large companies become purveyors of ES subject to remuneration (clean water market, sludge treatment market, ecotourism market, etc.), thereby echoing the discourse on environmental goods and services that OECD governments and parties to the World Trade Organization wish to liberalize.

\section{Conclusions}

This article contributes to the debate on ES notions and its implementation. The debate is whether the predominance of monetary and market-based tools is inherent in the ES concept or whether it is simply related to how the concept is used. Opinions differ (Corbera et al., 2007; Muradian et al., 2010a, b; Matulis, 2013, 2014; Barnaud and Antona, 20I4; Maris, 20I4; Corbera, 20I5). Some argue that the concept did not originally have a monetary or market connotation but was appropriated by economic actors. Others consider instead that the word 'service', in today's 
world, unavoidably echoes a market relationship, which is then inherent in the ES concept. In this way, 'ecosystemn services' is a concept to develop MBIs. In this article, we showed that business actors were mobilized in favour of ES as a concept to develop MBIs.

The preceding analysis shows the role played by businesses in promoting MBIs for ES. The involvement of industry in the international biodiversity assessment appears to be a part of a strategy to promote MBIs. Before the MEA, companies were involved in three coalitions: the GHG pro-trading coalition, the voluntary private standard coalition and the PES coalition. They all advocated a particular style of regulation that gave an overwhelming emphasis to the private sector and market-based policy instruments. WBCSD representatives and corporate experts from the three coalitions identified were recruited to participate in the MEA. Thanks to the political visibility given to the ES concept by the MEA, private industry had an occasion to strengthen and legitimize their actions in favour of market-based environmental governance. Associating private sector representatives with the Millennium Assessment process made it easier to disseminate the concept, and at the same time these business representatives, by appropriating it, have been able to modify the concept so that ES have become more and more tightly linked to market mechanisms - in line with their vision of the world, their beliefs and strategies.

In this way, a comprehensive analysis of business involvement in the MEA contributes to a better understanding of the politics on MBIs for ES. Our hypothesis is confirmed because we showed that the process by which information is generated and delivered affects the potential of that information process to influence outcomes. We demonstrated that businesses influenced the discourse on styles of regulatory policies. Also, the perspective of advocacy coalitions has proven to be helpful in analysing the engagement of business in global environmental politics and more particularly in scientific global arenas such as the MEA and soon in the Intergovernmental Platform on Biodiversity and ES (IPBES) (Hrabanski and Pesche, 20I6). Transnational coalitions have become an important vehicle to represent the interests of companies in global environmental politics. By exploring the political and discursive dimensions of MBIs for ES, this research has demonstrated the influence of powerful stakeholders in promoting a concept that is presently becoming central to public policies. Having shown how the link between 'ecosystem services' and incentive mechanisms is socially constructed, in line with the strategies and interests of corporate actors, our examination contributes to a better understanding of the introduction and implementation of MBIs for ES.

\section{References}

Barnaud C, Antona M. 20I4. Deconstructing ecosystem services: uncertainties and controversies around a socially constructed concept. Geoforum 56: II3-I23. https://doi.org/Io.IoI6/j.geoforum.2014.07.003.

Boiral O. 2005. Concilier environnement et compétitivité, ou la quête de l'éco-efficience. Revue Française de Gestion 5(158): I63-I86. https://doi. org/10.3166/rfg.158.163-186.

Boisvert V, Méral P, Froger G. 2013. Market-based instruments for ecosystem services: institutional innovation or renovation? Society and Natural Resources 26(Iо): II22-II36. https://doi.org/10.1080/08941920.2013.820815.

Broughton E, Pirard R. 20II. What's in a name? Market-based instruments for biodiversity. Health and Environnement Reports 8.

Clapp J. 2005. Global environmental governance for corporate responsibility and accountability. Global Environmental Politics 5(3): 23-34. https:// doi.org/ı.1162/1526380054794916.

Clapp J, Dauvergne P. 2005. Paths to a Green World: the Political Economy of the Global Environment. MIT Press: Cambridge, MA.

Coen D. 2005. Environmentaland business lobbying alliances in Europe: Learning from Washington? In The Business of Global Environmental Governance, Levy DL, Newell PJ (eds). MIT Press: Cambridge, MA; I97-222.

Corbera E. 20I5. Valuing nature, paying for ecosystem services and realizing social justice: A response to Matulis. Ecological Economics IIo: I54-I57. https://doi.org/I0.I0I6/j.ecolecon.20I4.I2.0I7.

Corbera E, Brown K, Adger WN. 2007. The equity and legitimacy of markets for ecosystem services. Development and Change 38(4): 587-613. https://doi.org/IO.IIII/j.I467-7660.2007.00425.x.

Dahan Damedico A, Guillemot H. 2006. Changement climatique: dynamiques scientifiques, expertise, enjeux politiques. Revue de sociologie du travail 48(3): 4I2-432 https://doi.org/I0.IOI6/j.soctra.2006.05.00I.

Dempsey J, Robertson MM. 20I2. Ecosystem services: tensions, impurities, and points of engagement within neoliberalism. Progress in Human Geography 36(6): 758-779. https://doi.org/10.1177/0309132512437076.

Dolowitz D, Marsh D. 1996. Who learns whatfrom whom: a review of the policy transfer literature. Political Studies 44(2): 343-357. https://doi. org/Io.IIII/j.I467-9248.1996.tboo334.x 
Engel S, Pagiola S, Wunder S. 2008. Designing payments for environmental services in theory and practice: an overview of the issues. Ecological Economics 65(4): 663-674. https://doi.org/10.1016/j.ecolecon.2008.03.011.

Ezzine-de-Blas D, Hrabanski M, Le Coq J-F. 2or6. Payment for Environmental Services in Climate Change Policies. Climate Change and Agriculture Worldwide. Springer: Berlin.

Farley J, Costanza R. 20I0. Payments for ecosystem services: from local to global. Ecological Economics 69(II): 2060-2068.

Fletcher R, Breitling J. 20I2. Market mechanism or subsidy in disguise? Governing payment for environmental services in Costa Rica. Geoforum 43(3): 402-4II. https://doi.org/IO.IOI6/j.geoforum.20II.II.oo8.

Fouilleux E. 20I0. Entre Internationalisation et privatisation des politiques agricoles. In Les mondes agricoles en politique, Hervieu B, Mayer N, Muller P, Purseigle F, Rémy J (eds). Paris Presses de: Sciences-po.

GEF. 200I. Global: Millenium Assessment of the State of the World's Ecosystem. Washington: GEF.

Gómez-Baggethun E, de Groot R, Lomas PL, Montes C. 20IO. The history of ecosystem services in economic theory and practice: From early notions to markets and payment schemes. Ecological Economics 69(6): 1209-I218.

Grossman E, Saurugger S. 2006. Les groupes d'intérêt. Action collective et stratégies de représentation. Armand Colin: Paris.

Haas PM. I992. Introduction: epistemic communities and international policy coordination. International Organization 46(oI): I-35. https://doi. org/I0.IOI7/So0208I830000I442.

Hrabanski M. 20I0. Les groupes d'experts de la DG Agri:Diversité des usages de l'expertise et socialisation aux normes d'action publique de l'Union européenne. Politique Européenne 32: 99-123.

Hrabanski M, Bidaud C, Le Coq J-F, Méral P. 20I3. Environmental NGOs, policy entrepreneurs of market-based instruments for ecosystem services? A comparison of Costa Rica, Madagascar and France. Forest Policy and Economics 37: I24-I32. https://doi.org/IO.IOI6/j. forpol.20I3.09.00I.

Hrabanski M, Pesche D. 20I6. The Intergovernmental Platform on Biodiversity and Ecosystem Services (IPBES): Meeting the Challenge of Biodiversity Conservation and Governance. Routledge: London.

Jeanneaux P, Aznar, O. 20I0. Analyse bibliométrique de la notion de service environnemental Note de synthèse WPI et WP2, document de travail no 2010-02: Projet Serena.

Krasner SD. 1983. International Regimes. Cornell University Press: Ithaca, NY.

Landell-Mills N, Porras T. 2002. Silver bullet or fools gold? A global review of markets for forest environmental services and their impact on the poor. International Institute for Environment and Development: London (Instruments for Sustainable Private Sector Forestry Series).

Le Prestre PG. 2005. Protection de l'environnement et relations internationales. Dalloz: Paris.

Levy DL, Newell P. 2005. Introduction. In The Business of Global Environnmental Governance, Levy DL, Newell P (eds). MIT Press: Cambridge, MA.

Maris V. 20I4. Nature à vendre: Les limites des services écosystémiques. Editions Quae.

Matulis BS. 2013. The narrowing gap between vision and execution: neoliberalization of PES in Costa Rica. Geoforum 44: 253-260. https://doi. org/I0.I0I6/j.geoforum.20I2.09.00I.

Matulis BS. 20I4. The economic valuation of nature: a question of justice? Ecological Economics IO4: I55-I57. https://doi.org/IO.IOI6/j. ecolecon.2014.04.010.

Meckling J. 20II. The globalization of carbon trading: transnational business coalitions in climate politics. Global Environmental Politics II(2): 26-50. https://doi.org/IO.II62/GLEP_a_00052.

Méral P. 20I2. Origine et portée du concept de service écosystèmique en économie. Natures Sciences Sociétés 20(I): 3-I5. https://doi.org/IO.IO5I/ nss/2012002.

Mitchell RB, Clark WC, Cash DW, Dickson NM. 2006. Global Environmental Assessments: Information and Influence. MIT Press: Cambridge, MA.

Muradian R, Corbera E, Pascual U, Kosoy N, May PH. 20Ioa. Reconciling theory and practice: an alternative conceptual framework for understanding payments for environmental services. Ecological Economics 69(6): I202-I208. https://doi.org/Io.IOI6/j.ecolecon. 2009.II.006.

Muradian R, Corbera E, Pascual U, Kosoy NP, May PH. 2oIob. Reconciling theory and practice: an alternative conceptual framework for understanding payments for environmental services. Ecological Economics 69(6): I202-I208. https://doi.org/Io.Ior6/j.ecolecon. 2009.II.006.

OECD. I997. Evaluating Economic Instruments for Environmental Policy. OECDE Publishing: Paris.

OECD. 2003. Harnessing Markets for Biodiversity: Towards Conservation and Sustainable Use. OECD: Paris.

OECD. 2007. Business and the Environment: Policy Incentives and Corporate Responses. OECD: Paris.

Orsini A. 20ıо. La Biodiversité sous influence? Les lobbies industriels face aux politiques internationales de l'environnement. Editions de l'Université libre de Bruxelles: Bruxelles.

Paterson M. I993. The politics of climate change after UNCED. Environmental Politics 2(4): I74-I90. https://doi.org/IO.Io80/ 096440I93084I4IO8.

Pesche D, Méral P, Hrabanski M, Bonnin M. 2013. Ecosystem services and payments for environmental services: two sides for the same coin? In Governing the Provision of Ecosystem Services, Muradian R, Rival L (eds). Springer: Berlin.

Pirard R. 20I2. Market-based instruments for biodiversity and ecosystem services: a lexicon. Environmental Science and Policy I9-20(May/June): $59-68$.

Redford KH, Adams WM. 2009. Payment for ecosystem services and the challenge of saving nature. Conservation Biology 23(4): $785-787$ https:// doi.org/I0.IIII/j.I523-I739.2009.0127I.x] [Pubmed:'ı9627303].

Sabatier PA, Jenkins-Smith HC. I993. Policy Change and Learning. An Advocacy Coalition Approach. Wespoint: Boulder, CO. 
Schomers S, Matzdorf B. 20I3. Payments for ecosystem services: a review and comparison of developing and industrialized countries. Ecosystem Services 6: I6-30. https://doi.org/I0.IoI6/j.ecoser.2013.01.002.

Shapiro-Garza E. 20I3. Contesting the market-based nature of Mexico's national payments for ecosystem services programs: four sites of articulation and hybridization. Geoforum 46: 5-15. https://doi.org/10.IoI6/j.geoforum.2012.II.oI8.

Sikor T. 2013. The Justices and Injustices of Ecosystem Services. Routledge: London.

Stephens JC, Hansson A, Liu Y, de Coninck H, Vajjhala S. 2oII. Characterizing the international carbon capture and storage community. Global Environmental Change 2I(2): 379-390. https://doi.org/10.10I6/j.gloenvcha.20II.oI.008.

Vormedal I. 2008. The influence of business and industry NGOs in the negotiation of the Kyoto mechanisms: the case of carbon capture and storage in the CDM. Global Environmental Politics 8(4): 36-65 [doi: ]. http://muse.jhu.edu/journals/global_environmental_politics/voo8/ 8.4.vormedal.html Ni.

Wolff F, Schmitt K. 2009. In hunt for sustainable seafood: sustainability effects of CSR in three fish processing companies. In Analysing Corporate Social Responsibility in Europe: Rhetoric and Realities, Barth R, Wolff F (eds). Edward Elgar Publishing: Cheltenham; I57-I89.

Wunder S. 2005. Payment for Environmental Services: Some Nuts and Bolts. Centre for International Forestry Research: Bogor, Indonesia. 


\section{Author Query Form}

\section{Journal: Environmental Policy and Governance}

\section{Article: eet_1780}

Dear Author,

During the copyediting of your paper, the following queries arose. Please respond to these by annotating your proofs with the necessary changes/additions.

- If you intend to annotate your proof electronically, please refer to the E-annotation guidelines.

- If you intend to annotate your proof by means of hard-copy mark-up, please use the standard proofing marks. If manually writing corrections on your proof and returning it by fax, do not write too close to the edge of the paper. Please remember that illegible mark-ups may delay publication.

Whether you opt for hard-copy or electronic annotation of your proofs, we recommend that you provide additional clarification of answers to queries by entering your answers on the query sheet, in addition to the text mark-up.

\begin{tabular}{|c|l|c|}
\hline Query No. & \multicolumn{1}{|c|}{ Query } & Remark \\
\hline Q1 & $\begin{array}{l}\text { AUTHOR: Please confirm that given names (red) and surnames/family names } \\
\text { (green) have been identified correctly. }\end{array}$ & $\begin{array}{l}\text { AUTHOR: "Agence Nationale de la Recherche" was identified as funder in the } \\
\text { supplied metadata, however, this funder was not mentioned in the } \\
\text { acknowledgments or funding information section. Please insert the appropriate } \\
\text { text for this funder, or confirm that this is to be deleted from the funders list. }\end{array}$ \\
\hline Q3 & AUTHOR: Please add a text citation for Table 1. & \\
\hline Q4 & $\begin{array}{l}\text { AUTHOR: Please ensure that all abbreviations that you have introduced are used } \\
\text { consistently thereafter. }\end{array}$ & \\
\hline Q5 & AUTHOR: No matching reference was found for Ehrlichand Ehrlich, 1981. & \\
\hline Q6 & AUTHOR: No matching reference was found for MEA 2005. & \\
\hline Q7 & AUTHOR: Fouilleux, 2010: 000, please add page details for this quote. & \\
\hline Q8 & AUTHOR: No citation to Dolowitz and Marsh 1996 was found. & \\
\hline
\end{tabular}

Please confirm that the funding sponsor list below was correctly extracted from your article: that it includes all funders and that the text has been matched to the correct FundRef Registry organization names. If a name was not found in the FundRef registry, it may not be the canonical name form, it may be a program name rather than an organization name, or it may be an organization not yet included in FundRef Registry. If you know of another name form or a parent organization name for a "not found" item on this list below, please share that information.

\begin{tabular}{|l|l|}
\hline FundRef Name & FundRef Organization Name \\
\hline Agence Nationale de la Recherche & Agence Nationale de la Recherche \\
\hline
\end{tabular}

